\title{
Temporal trends in pregnancy weight gain and birth weight in Bavaria 2000-2007: slightly decreasing birth weight with increasing weight gain in pregnancy*
}

\author{
Barbara Schiess| ${ }^{1, * *}$, Andreas Beyerlein ${ }^{2}$, \\ Nicholas Lack ${ }^{3}$ and Rüdiger von Kries ${ }^{2}$ \\ 1 Department of Obstetrics and Gynecology, \\ Ludwig-Maximilians-University, Munich, Germany \\ 2 Institute of Social Pediatrics and Adolescent Medicine, \\ Ludwig Maximilians-University, Munich, Germany \\ ${ }^{3}$ Bayerische Arbeitsgemeinschaft Qualitätssicherung in \\ der stationären Versorgung-Bavarian Quality \\ Assurance for In-Patient Medical Care, Munich, \\ Germany
}

\begin{abstract}
Aims: To assess temporal trends in birth weight and pregnancy weight gain in Bavaria from 2000 to 2007. Methods: Data on 695,707 mother and infant pairs (singleton term births) were available from a compulsory reporting system for quality assurance, including information on birth weight, maternal weight at delivery and at booking, maternal smoking, age, and further anthropometric and lifestyle factors. Pregnancy weight gain was defined as: weight prior to delivery minus weight at first booking minus weight of the newborn.

Results: Although mean weight gain during pregnancy increased considerably from 10.10 to $10.73 \mathrm{~kg}$ in seven years, the mean birth weight in mature singletons decreased slightly from 3433 to $3414 \mathrm{~g}$. These trends could not be explained by concurrent changes in the rates of primiparity, smoking and gestational diabetes.

Conclusions: These German data confirm an increased weight gain during pregnancy with adjustment for potential confounders.
\end{abstract}

Keywords: Birth weight; maternal weight; pregnancy weight gain; temporal trends.

\footnotetext{
${ }^{*}$ The study was supported by the PEPO-Project (BMBF-funding 2008).

${ }^{\star *}$ Corresponding author:

Barbara Schiessl, MD

First Department of Obstetrics and Gynecology

Ludwig-Maximilans-University

Prenatal Medicine Unit

Maistr. 11

80337 Munich

Germany

E-mail: Barbara.Schiessı@med.uni-muenchen.de
}

\section{Introduction}

Increasing numbers of obese children have been reported in various countries all over the world [1, 7, 19]. Several studies have focused on early risk factors for childhood obesity like high birth weight and maternal weight gain in pregnancy $[4,13,15]$. High birth weight ( $>90^{\text {th }}$ percentile, or $>4000 \mathrm{~g}$ ) is an established risk factor for obesity in later life. Recently, associations between maternal weight gain in pregnancy and offspring overweight were found in Portugal where high weight gain in pregnancy $(>16 \mathrm{~kg})$ was associated with a higher risk of overweight in 6-12-year-old children. It was shown by Oken et al. that gestational weight gain was directly associated with child overweight at three years $[13,14]$. A recent study reported increases in both variables over time [4], in keeping with reports from other countries on birth weight and gestational weight gain in the last decades $[10,11,16]$.

We examined time trends in maternal pregnancy weight gain and birth weight from 2000 to 2007 in Bavaria, Germany, with a focus on potentially confounding factors.

\section{Materials and methods}

We restricted our analyses to mature singletons born at $\geq 37$ completed weeks' gestation or later. Gestational age was calculated from the last menstrual period (LMP) and confirmed or otherwise corrected by first trimester ultrasound.

Maternal and neonatal data were analysed on $n=695,707$ mature singleton deliveries in obstetric units in Bavaria, Germany, from 2000 to 2007. Due to closure of smaller units as well as merging of other units, and following a general reorganisation of hospital structure in Bavaria, some of the coding of unit identifiers changed. The BAQ databases (Bayerische Arbeitsgemeinschaft für Qualitätssicherung-Bavarian working group on quality assurance in outpatient Medical care) are continuously updated giving precedence to current years. As a result, data from five units for the years 2001-2003 were excluded from the analysis, but the effect on the reported rates was considered negligible. Anthropometric measurements of pregnant women during pregnancy as well of the newborns were documented and stored electronically.

All data analysed in this study were extracted from a standard data set regularly collected electronically for the purpose of benchmarking obstetric wards in terms of clinical performance. The BAQ conducts corresponding analyses for the "Bundesland 
of Bavaria". Data are transferred electronically to the BAQ office after personal identifying characteristics have been removed from individual records and replaced by an anonymous unique reference number.

Information on maternal weight and gestational age at booking were extracted from the maternal pregnancy chart, information on smoking was obtained by interview when admitted to hospital. Neonatal anthropometric data were abstracted from the hospital notes. Weight gain in pregnancy was calculated as last weight prior to delivery minus maternal weight at booking minus neonatal birth weight (rounded to $\mathrm{kg}$ ), if booking was prior to the $13^{\text {th }}$ week of gestation. Otherwise weight gain was set as missing ( $n=133,467 ; 19.18 \%)$.

According to the coding of the BAQ, "German" means born in Germany or of German origin. All calculations were based on "available case analysis": we included all cases with available information on the respective covariates analysed. Apart from gestational weight gain, further missing values considered smoking during pregnancy $(n=117,095 ; 16.83 \%)$, maternal prepregnancy BMI $(n=58,351 ; 8.39 \%)$, maternal height $(n=54,339$; $7.1 \%)$, birth weight $(n=3645 ; 0.52 \%)$, maternal age $(n=447$, $0.06 \%)$ and child's gender $(n=170 ; 0.02 \%)$. These numbers do not add up to $100 \%$, because of multiple missing values. In total, there were $n=477,717$ cases $(68.67 \%)$ with complete values.

\section{Results}

Table 1 shows the birth weight and pregnancy weight gain of mothers of singleton term births (including stillbirths) in Bavaria from 2000 to 2007. We observed slight decreases in mean birth weight and in the percentage of newborns weighing $\geq 4000 \mathrm{~g}$. Mean maternal pregnancy weight gain gradually increased from 10.10 to $10.73 \mathrm{~kg}$ as well as the proportion of mothers gaining $>16 \mathrm{~kg}$ during pregnancy.
Table 2 shows temporal trends of potential confounders. An increase was observed regarding mean maternal age and the proportions of primiparous mothers, as well as the proportions of caesarean sections and gestational diabetes. Mean maternal height and pre-pregnancy BMI remained stable during the observed time period. Smoking during pregnancy decreased over time.

Table 3 shows the birth weight and maternal weight gain stratified by maternal smoking in pregnancy, parity, and gestational diabetes. Significant temporal trends had been observed for these three binary variables (Table 2). Both mean birth weight and the proportion of high birth weight were higher in children to non-smoking mothers, multiparous mothers and mothers with gestational diabetes, respectively. Lower pregnancy weight gain was observed for non-smoking mothers, multiparous mothers and pregnancies with gestational diabetes.

An increasing proportion of primiparous mothers was associated with an increased weight gain and a decreased birth weight (Tables 1 and 2). The observed decreased birth weight and the increased weight gain in pregnancy over time might therefore be explained by the observed increased proportions of deliveries to primiparous mothers.

A stratified analysis of temporal trends in birth weight and weight gain in pregnancy confined to primiparous mothers showed similar trends (Table 4), indicating that they cannot be explained by changes in the proportion of primiparous mothers alone.

\section{Discussion}

The main finding of this analysis is an increase in weight gain in pregnancy associated with a slight decrease in

Table 1 Total numbers (n), mean birth weight (BW) in grams and mean maternal pregnancy weight gain in kilograms (WG) of singleton mature births in Bavarian hospitals from 2000 to 2007. P-values for Cochran-Armitage test for trend are given for each column.

\begin{tabular}{|c|c|c|c|c|c|c|}
\hline Year & $\mathrm{n}$ & $\begin{array}{l}\text { Mean BW } \\
(95 \% \mathrm{Cl})\end{array}$ & $\begin{array}{l}B W \geq 4000 \mathrm{~g} \\
(95 \% \mathrm{Cl})\end{array}$ & $\begin{array}{l}\mathrm{BW}<2500 \mathrm{~g} \\
(95 \% \mathrm{Cl})\end{array}$ & $\begin{array}{l}\text { Mean WG } \\
(95 \% \mathrm{Cl})\end{array}$ & $\begin{array}{l}\text { WG }>16 \mathrm{~kg} \\
(95 \% \mathrm{Cl})\end{array}$ \\
\hline 2000 & 88,361 & $\begin{array}{l}3433 \\
(3430,3436)\end{array}$ & $\begin{array}{l}10.3 \% \\
(10.1,10.5)\end{array}$ & $\begin{array}{l}1.77 \% \\
(1.68,1.86)\end{array}$ & $\begin{array}{l}10.10 \\
(10.05,10.15)\end{array}$ & $\begin{array}{l}9.9 \% \\
(9.7,10.1)\end{array}$ \\
\hline 2001 & 78,771 & $\begin{array}{l}3431 \\
(3428,3434)\end{array}$ & $\begin{array}{l}10.1 \% \\
(9.9,10.3)\end{array}$ & $\begin{array}{l}1.91 \% \\
(1.81,2.01)\end{array}$ & $\begin{array}{l}10.34 \\
(10.29,10.39)\end{array}$ & $\begin{array}{l}10.5 \% \\
(10.3,10.7)\end{array}$ \\
\hline 2002 & 77,503 & $\begin{array}{l}3424 \\
(3421,3427)\end{array}$ & $\begin{array}{l}10.0 \% \\
(9.8,10.2)\end{array}$ & $\begin{array}{l}1.98 \% \\
(1.88,2.08)\end{array}$ & $\begin{array}{l}10.49 \\
(10.45,10.53)\end{array}$ & $\begin{array}{l}10.4 \% \\
(10.2,10.6)\end{array}$ \\
\hline 2003 & 80,109 & $\begin{array}{l}3415 \\
(3412,3418)\end{array}$ & $\begin{array}{l}9.6 \% \\
(9.4,9.8)\end{array}$ & $\begin{array}{l}1.86 \% \\
(1.77,1.95)\end{array}$ & $\begin{array}{l}10.47 \\
(10.44,10.51)\end{array}$ & $\begin{array}{l}10.5 \% \\
(10.3,10.7)\end{array}$ \\
\hline 2004 & 91,422 & $\begin{array}{l}3415 \\
(3412,3418)\end{array}$ & $\begin{array}{l}9.4 \% \\
(9.2,9.6)\end{array}$ & $\begin{array}{l}1.97 \% \\
(1.88,2.06)\end{array}$ & $\begin{array}{l}10.56 \\
(10.52,10.60)\end{array}$ & $\begin{array}{l}10.7 \% \\
(10.5,10.9)\end{array}$ \\
\hline 2005 & 93,361 & $\begin{array}{l}3417 \\
(3414,3420)\end{array}$ & $\begin{array}{l}9.5 \% \\
(9.3,9.7)\end{array}$ & $\begin{array}{l}1.78 \% \\
(1.70,1.86)\end{array}$ & $\begin{array}{l}10.58 \\
(10.54,10.62)\end{array}$ & $\begin{array}{l}10.9 \% \\
(10.7,11.1)\end{array}$ \\
\hline 2006 & 92,195 & $\begin{array}{l}3414 \\
(3411,3417)\end{array}$ & $\begin{array}{l}9.6 \% \\
(9.4,9.8)\end{array}$ & $\begin{array}{l}1.80 \% \\
(1.71,1.89)\end{array}$ & $\begin{array}{l}10.67 \\
(10.63,10.71)\end{array}$ & $\begin{array}{l}11.6 \% \\
(11.4,11.8)\end{array}$ \\
\hline 2007 & 93,985 & $\begin{array}{l}3414 \\
(3411,3417)\end{array}$ & $\begin{array}{l}9.4 \% \\
(9.2,9.6)\end{array}$ & $\begin{array}{l}1.78 \% \\
(1.70,1.86)\end{array}$ & $\begin{array}{l}10.73 \\
(10.69,10.77)\end{array}$ & $\begin{array}{l}12.1 \% \\
(11.9,12.3)\end{array}$ \\
\hline P Trend & - & $0.02^{*}$ & $0.02^{*}$ & 0.39 & $0.01^{*}$ & $0.01^{*}$ \\
\hline
\end{tabular}

*Significant $(\mathrm{P}<0.05)$. 


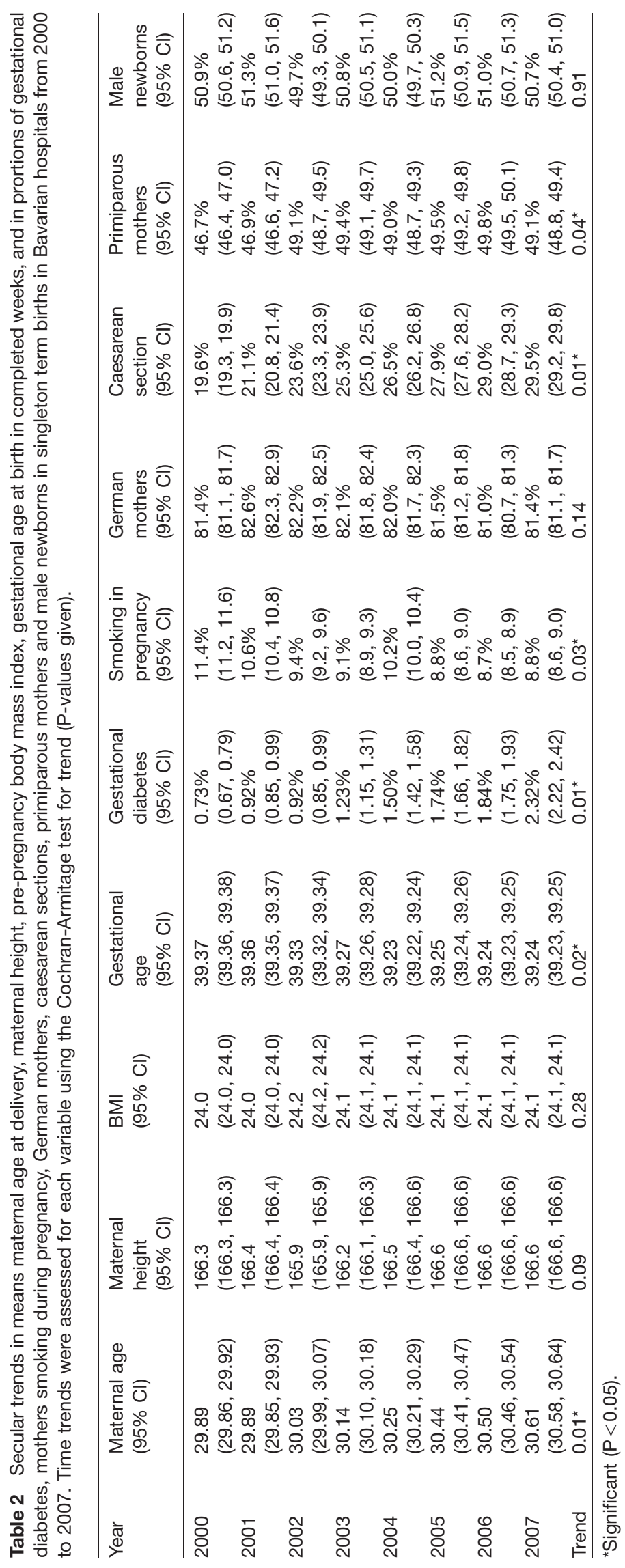


Table 3 Mean birth weight and weight gain during pregnancy stratified by smoking, parity and gestational diabetes.

\begin{tabular}{|c|c|c|c|c|c|c|}
\hline & $\mathrm{n}$ & $\begin{array}{l}\text { Mean BW } \\
(95 \% \mathrm{CI})\end{array}$ & $\begin{array}{l}\mathrm{BW} \geq 4000 \mathrm{~g} \\
(95 \% \mathrm{Cl})\end{array}$ & $\begin{array}{l}\mathrm{BW}<2500 \mathrm{~g} \\
(95 \% \mathrm{Cl})\end{array}$ & $\begin{array}{l}\text { Mean WG } \\
(95 \% \mathrm{Cl})\end{array}$ & $\begin{array}{l}W G>16 \mathrm{~kg} \\
(95 \% \mathrm{Cl})\end{array}$ \\
\hline \multicolumn{7}{|c|}{ Smoking } \\
\hline No & 522,143 & $\begin{array}{l}3438 \\
(3437,3439)\end{array}$ & $\begin{array}{l}10.1 \% \\
(10.0,10.2)\end{array}$ & $\begin{array}{l}1.54 \% \\
(1.51,1.57)\end{array}$ & $\begin{array}{l}10.47 \\
(10.45,10.49)\end{array}$ & $\begin{array}{l}10.6 \% \\
(10.5,10.7)\end{array}$ \\
\hline Yes & 55,330 & $\begin{array}{l}3237 \\
(3233,3241)\end{array}$ & $\begin{array}{l}5.0 \% \\
(4.8,5.2)\end{array}$ & $\begin{array}{l}5.06 \% \\
(4.88,5.24)\end{array}$ & $\begin{array}{l}10.79 \\
(10.73,10.85)\end{array}$ & $\begin{array}{l}12.6 \% \\
(12.3,12.9)\end{array}$ \\
\hline \multicolumn{7}{|c|}{ Parity } \\
\hline $\mathrm{PP}$ & 355,796 & $\begin{array}{l}3360 \\
(3358,3362)\end{array}$ & $\begin{array}{l}7.3 \% \\
(7.2,7.4)\end{array}$ & $\begin{array}{l}2.00 \% \\
(1.95,2.05)\end{array}$ & $\begin{array}{l}11.49 \\
(11.47,11.51)\end{array}$ & $\begin{array}{l}14.8 \% \\
(14.7,14.9)\end{array}$ \\
\hline MP & 336,266 & $\begin{array}{l}3477 \\
(3475,3479)\end{array}$ & $\begin{array}{l}12.0 \% \\
(11.9,12.1)\end{array}$ & $\begin{array}{l}1.71 \% \\
(1.67,1.75)\end{array}$ & $\begin{array}{l}9.55 \\
(9.53,9.57)\end{array}$ & $\begin{array}{l}7.1 \% \\
(7.0,7.2)\end{array}$ \\
\hline \multicolumn{7}{|c|}{ Gest. diabetes } \\
\hline No & 682,122 & $\begin{array}{l}3419 \\
(3418,3420)\end{array}$ & $\begin{array}{l}9.6 \% \\
(9.5,9.7)\end{array}$ & $\begin{array}{l}1.86 \% \\
(1.83,1.89)\end{array}$ & $\begin{array}{l}10.52 \\
(10.50,10.54)\end{array}$ & $\begin{array}{l}10.8 \% \\
(10.7,10.9)\end{array}$ \\
\hline Yes & 9940 & $\begin{array}{l}3499 \\
(3489,3509) \\
\end{array}$ & $\begin{array}{l}14.6 \% \\
(13.9,15.3)\end{array}$ & $\begin{array}{l}1.57 \% \\
(1.37,1.77)\end{array}$ & $\begin{array}{l}8.75 \\
(8.61,8.89) \\
\end{array}$ & $\begin{array}{l}9.2 \% \\
(8.6,9.8) \\
\end{array}$ \\
\hline
\end{tabular}

$\mathrm{PP}=$ primiparous, $\mathrm{MP}=$ multiparous.

mean birth weight and in the proportion of high birth weight children in Bavaria since the beginning of the millennium. Additionally, our results show increasing numbers of gestational diabetes and falling trends for smoking (Table 2) which would be expected to lead to some decrease in gestational weight gain (Table 3), but actually lead to an increase (Table 1).

The inverse association in time of gestational diabetes and gestational weight gain might be explained by nutritional interventions in mothers with gestational diabetes. It is difficult to find a reason for the association of increasing gestational weight gain and decreasing smok- ing in pregnancy, however. The slight decrease in mean birth weight might have been caused by earlier delivery, since the mean gestational age at delivery decreased slightly over time. The decreasing mean gestational age, again, might be explained by increasing numbers of caesarean sections.

Other confounding factors are unlikely to account for the observed changes: it is implausible that a decreased gestational age leads to an increase in weight gain. Therefore, only the increasing proportion of primiparous mothers might account for the observed trends of birth weight and weight gain. One might expect a decrease in

Table 4 Total numbers (n), mean birth weight (BW) and mean maternal pregnancy weight gain (WG) in primiparous singleton deliveries in Bavarian hospitals from 2000 to 2007. P-values trend were assessed by the Cochran-Armitage-test.

\begin{tabular}{|c|c|c|c|c|c|c|}
\hline Year & $n$ & $\begin{array}{l}\text { Mean birth } \\
\text { weight } \\
(95 \% \mathrm{Cl})\end{array}$ & $\begin{array}{l}\mathrm{BW} \geq 4000 \mathrm{~g} \\
(95 \% \mathrm{Cl})\end{array}$ & $\begin{array}{l}\mathrm{BW}<2500 \mathrm{~g} \\
(95 \% \mathrm{Cl})\end{array}$ & $\begin{array}{l}\text { Mean weight } \\
\text { gain } \\
(95 \% \mathrm{Cl})\end{array}$ & $\begin{array}{l}\text { Weight } \\
\text { gain > }>16 \mathrm{~kg} \\
(95 \% \mathrm{Cl})\end{array}$ \\
\hline 2000 & 41,267 & $\begin{array}{l}3364 \\
(3360,3368)\end{array}$ & $\begin{array}{l}7.5 \% \\
(7.2,7.8)\end{array}$ & $\begin{array}{l}1.83 \% \\
(1.70,1.96)\end{array}$ & $\begin{array}{l}11.12 \\
(11.06,11.18)\end{array}$ & $\begin{array}{l}13.7 \% \\
(13.4,14.0)\end{array}$ \\
\hline 2001 & 36,944 & $\begin{array}{l}3365 \\
(3361,3369)\end{array}$ & $\begin{array}{l}7.5 \% \\
(7.2,7.8)\end{array}$ & $\begin{array}{l}1.81 \% \\
(1.67,1.95)\end{array}$ & $\begin{array}{l}11.38 \\
(11.32,11.44)\end{array}$ & $\begin{array}{l}14.6 \% \\
(14.2,15.0)\end{array}$ \\
\hline 2002 & 38,051 & $\begin{array}{l}3361 \\
(3357,3365)\end{array}$ & $\begin{array}{l}7.7 \% \\
(7.4,8.0)\end{array}$ & $\begin{array}{l}1.90 \% \\
(1.76,2.04)\end{array}$ & $\begin{array}{l}11.45 \\
(11.37,11.53)\end{array}$ & $\begin{array}{l}14.2 \% \\
(13.8,14.6)\end{array}$ \\
\hline 2003 & 39,545 & $\begin{array}{l}3356 \\
(3352,3360)\end{array}$ & $\begin{array}{l}7.1 \% \\
(6.8,7.4)\end{array}$ & $\begin{array}{l}1.81 \% \\
(1.68,1.94)\end{array}$ & $\begin{array}{l}11.45 \\
(11.38,11.52)\end{array}$ & $\begin{array}{l}14.4 \% \\
(14.1,14.7)\end{array}$ \\
\hline 2004 & 44,779 & $\begin{array}{l}3354 \\
(3350,3358)\end{array}$ & $\begin{array}{l}7.1 \% \\
(6.9,7.3)\end{array}$ & $\begin{array}{l}2.10 \% \\
(1.97,2.23)\end{array}$ & $\begin{array}{l}11.55 \\
(11.48,11.62)\end{array}$ & $\begin{array}{l}14.5 \% \\
(14.2,14.8)\end{array}$ \\
\hline 2005 & 46,198 & $\begin{array}{l}3359 \\
(3355,3363)\end{array}$ & $\begin{array}{l}7.3 \% \\
(7.0,7.6)\end{array}$ & $\begin{array}{l}2.19 \% \\
(2.06,2.32)\end{array}$ & $\begin{array}{l}11.55 \\
(11.50,11.60)\end{array}$ & $\begin{array}{l}14.7 \% \\
(14.4,15.0)\end{array}$ \\
\hline 2006 & 45,909 & $\begin{array}{l}3361 \\
(3357,3365)\end{array}$ & $\begin{array}{l}7.3 \% \\
(7.0,7.6)\end{array}$ & $\begin{array}{l}2.16 \% \\
(2.03,2.29)\end{array}$ & $\begin{array}{l}11.66 \\
(11.60,11.72)\end{array}$ & $\begin{array}{l}15.6 \% \\
(15.3,15.9)\end{array}$ \\
\hline 2007 & 46,118 & $\begin{array}{l}3359 \\
(3355,3363)\end{array}$ & $\begin{array}{l}7.2 \% \\
(6.9,7.5)\end{array}$ & $\begin{array}{l}2.14 \% \\
(2.01,2.27)\end{array}$ & $\begin{array}{l}11.74 \\
(11.68,11.80)\end{array}$ & $\begin{array}{l}16.3 \% \\
(16.0,16.6)\end{array}$ \\
\hline P Trend & - & 0.19 & 0.12 & $0.02^{*}$ & $0.01^{*}$ & $0.02^{*}$ \\
\hline
\end{tabular}

*Significant $(\mathrm{P}<0.05)$. 
mean birth weight with increasing percentage of primiparous mothers, as the first newborn weighs less than the second or third baby [6]. However, the observed trends for birth weight and pregnancy weight gain could not be explained by changes in parity in our data (Table 4).

These data are partially contrasting the report by Bergmann et al. [4] who reported a significant increased proportion of children weighing over $4000 \mathrm{~g}$ while observing a concomitant increased pregnancy weight gain in Berlin over a time period of seven years from 1993 to 1999 [4]. There are at least two possible explanations. There was a different ethnic mix in the population studied (81$82 \%$ German mothers in our data vs. $72-75 \%$ in Bergman's data), however, we did not observe an increased birth weight over time among the non-German population in Bavaria. Secular trends might be another explanation: the increase in birth weight could possibly be confined to the period of 1993-1999 [4]. Unfortunately, we do not have data from this time period in Bavaria.

Recently, Blissing et al. reported on increasing rates of maternal overweigth and obesity, showing decreasing birth weights, although the study included a small sample collected over a 25-year period and only concentrated on the population of Würzburg City [5].

According to a "priming concept" the risk for childhood obesity may be primed by the intrauterine environment [15]. Excessive weight gain during pregnancy has recently been reported to be a major risk factor for obesity in the offspring $[12,14]$. An increasing weight gain in pregnancy is an important finding pointing to a challenge in early prevention of childhood obesity. However, weight gain in pregnancy may be modified by nutritional and exercise interventions [2, 20] and such modification could have substantial impact on prevention of childhood overweight [12, 14, 17, 18].

The strength of the present data lies in the large number of pregnancies and neonates. The data were collected without any hypothesis and the quality of the data is high since completeness of the datasets is part of an annual audit defining the monitored performance of the obstetrical units.

However, the numbers of maternal smoking in pregnancy and gestational diabetes may have been underestimated. Since the diagnosis of gestational diabetes is improving, the increasing trend could be an indicator for better detection [3]. A further limitation of the data might be the calculation of weight gain in pregnancy, which was based on the weight at booking used as a surrogate for maternal pre-pregnancy weight. A similar approach was chosen by Carmichael and coworkers [8] and Cedergren [9] and appears justified since most mothers only start gaining weight after 12 weeks of pregnancy [8, 9]. Whereas maternal pre-pregnancy weight and weight at delivery were both given in $\mathrm{kg}$, birth weight was recorded in g. Therefore, gestational weight gain calculated as weight at delivery minus pre-pregnancy weight minus birth weight was accurate within the level of $\pm 1 \mathrm{~kg}$.

Our data confirm a potentially alarming trend in public health: an increasing average weight gain during pregnancy which may herald an increased risk for childhood obesity. Prevention of childhood obesity should begin in utero [15]. Therefore, strategies to optimize maternal weight gain in pregnancy - within defined limits deserve further consideration.

\section{References}

[1] Apfelbacher CJ, Loerbroks A, Cairns J, Behrendt H, Ring $\mathrm{J}$, Kraemer U. Predictors of overweight and obesity in five to seven-year-old children in Germany: results from crosssectional studies. BMC Public Health. 2008;8:171.

[2] Artal R, Catanzaro RB, Gavard JA, Mostello DJ, Friganza JC. A lifestyle intervention of weight-gain restriction: diet and exercise in obese women with gestational diabetes mellitus. Appl Physiol Nutr Metab. 2007;32:596-601.

[3] Bergmann KE, Bergmann RL, Ellert U, Dudenhausen JW. [Perinatal risk factors for long-term health. Results of the German Health Interview and Examination Survey for Children and Adolescents (KiGGS)]. Bundesgesundheitsblatt Gesundheitsforschung Gesundheitsschutz. 2007;50:6706.

[4] Bergmann RL, Richter R, Bergmann KE, Plagemann A, Brauer M, Dudenhausen JW. Secular trends in neonatal macrosomia in Berlin: influences of potential determinants. Paediatr Perinat Epidemiol. 2003;17:244-9.

[5] Blissing S, Roloff R, Girschik G, Frambach T, Dietl J. Neonatal results of prgenancies in overweight and obese mothers at the University of Würzburg Gynaecology Clinic - a comparison of the years 1980 and 2005. Z Geburtshilfe Neonatol. 2008;212:94-9.

[6] Bonellie S, Chalmers J, Gray R, Greer I, Jarvis S, Williams C. Centile charts for birthweight for gestational age for Scottish singleton births. BMC Pregnancy Childbirth. 2008;8:5.

[7] Budd GM, Hayman LL. Addressing the childhood obesity crisis: a call to action. MCN Am J Matern Child Nurs. 2008; 33:111-8, quiz.

[8] Carmichael S, Abrams B, Selvin S. The pattern of maternal weight gain in women with good pregnancy outcomes. Am J Public Health. 1997;87:1984-8.

[9] Cedergren MI. Optimal gestational weight gain for body mass index categories. Obstet Gynecol. 2007;110:759-64.

[10] Davidson S, Litwin A, Peleg D, Erlich A. Are babies getting bigger? Secular trends in fetal growth in Israel - a retrospective hospital-based cohort study. Isr Med Assoc J. 2007;9:649-51.

[11] Kinnunen TI, Luoto R, Gissler M, Hemminki E. Pregnancy weight gain from 1960s to 2000 in Finland. Int J Obes Relat Metab Disord. 2003;27:1572-7.

[12] Moreira P, Padez C, Mourao-Carvalhal I, Rosado V. Maternal weight gain during pregnancy and overweight in Portuguese children. Int J Obes. (Lond) 2007;31:608-14.

[13] Oken E, Gillman MW. Fetal origins of obesity. Obes Res. 2003;11:496-506.

[14] Oken E, Taveras EM, Kleinman KP, Rich-Edwards JW, Gillman MW. Gestational weight gain and child adiposity at age 3 years. Am J Obstet Gynecol. 2007;196:322-8. 
[15] Plagemann A, Harder T, Dudenhausen JW. The diabetic pregnancy, macrosomia, and perinatal nutritional programming. Nestle Nutr Workshop Ser Pediatr Program. 2008; 61:91-102.

[16] Schack-Nielsen L, Molgaard C, Sorensen TI, Greisen G, Michaelsen KF. Secular change in size at birth from 1973 to 2003: national data from Denmark. Obesity. (Silver Spring) 2006;14:1257-63.

[17] Schack-Nielsen L, Mortensen EL, Michaelsen KF, Tia S. High maternal pregnancy weight gain is associated with an increased risk of obesity in childhood and adulthood indepentend of maternal BMI (abstract). Pediatr Res. 58, 1020. 2005. Ref Type: Abstract.

[18] Seidman DS, Laor A, Shmer J, Galr R, DK S. Excessive maternal weight gain during pregnancy and being over- weight at 17 years of age (abstract). Pediatr Res. 39, 112A. 1996. Ref Type: Abstract.

[19] Wang Y, Lobstein T. Worldwide trends in childhood overweight and obesity. Int J Pediatr Obes. 2006;1:11-25.

[20] Wolff S, Legarth J, Vangsgaard K, Toubro S, Astrup A. A randomized trial of the effects of dietary counseling on gestational weight gain and glucose metabolism in obese pregnant women. Int J Obes. (Lond) 2008;32:495-501.

The authors stated that there are no conflicts of interest regarding the publication of this article.

Received August 11, 2008. Revised November 5, 2008. Accepted January 26, 2009. Previously published online March 23, 2009. 